\title{
REGIONAL CO-OPERATION
}

As country aiter country within the Commonwealth has achieved independence many of them have tended in the last decade to move towards increasing regional co-operation in many different spheres. Teacher education is no exception.

A most remarkable example has been the co-operation sponsored by the Afro-Anglo-American Programme, which was initiated by Teachers College Columbia University in the United States and the University of London Institute of Education in the United Kingdom, and financed by the Carnegie Corporation. Accounts of its work and achievements are to be found in the reports of its annual conferences, and in particular those of 1965 (131), 1967 (132) and 1969 (134). In 1969 this project was transformed into the Association for Teacher Education in Africa (A.T.E.A.) and is now under African leadership. Furthermore out of its annual conferences and the personal contacts they engendered were born two smaller Regional Councils for Teacher Education, first that for East Africa and subsequently that for West Africa which was founded in December 1969.

Before the birth of the Regional Council for Teacher Education in East Africa co-operation in that area had been based on the conferences sponsored by the University of East Africa in association with the American 'Teacher Education for East Africa' project: an account of the achievements of this co-operation is to be found in the resports of the annual conferences of 1965 (136), 1966 (137), 1967 (138) and 1968 (139).

As the University of East Africa has encouraged a measure of co-operation and consultation in that area, so also has the University of the West Indies Institute of Education encouraged co-operation in teacher education in the Caribbean. Elsa H. Walters in her article Teacher Training in the British West Indies' (104) writes of the institute of education as the only unifying organisation in teacher education in two Dominions and eleven colonies (in 1965). This co-operation is reflected in the Report of Conference on Teacher Education (St. Vincent, 1967) (155) and the Report of Conference on Teacher Education in the Eastern Caribbean (Antigua, 1968)(156). And it would appear that it is intended that School of Education of the University of the South Pacific should fulfil a similar role of leadership and co-ordination in that area also.

In Asia, however, it seems that co-operation and consultation in matters of teacher education have been developed around the UNESCO Regional Office for Education in Asia, Bangkok, from which centre have appeared such reports as Student Teacher Practices in Primary Teacher Training Institutes in Asia (78), A Study of the In-Service Training of Primary School Teachers in Asia (77), and Problems in Asian Teacher Training and a Course for Teacher Educators (129). 